\title{
YOU TUBE: uma opção para uso do vídeo na EAD
}

\author{
Saulo Vicente Nunes Caetano \\ Gilse A. Morgental Falkembach \\ saulo@saulo.pro.br, gilsemf@ terrra.com.br \\ Universidade Federal do Rio Grande do Sul
}

\begin{abstract}
Resumo
Este estudo pretende mostrar que mais do que uma nova mania mundial, o vídeo pode ser usado por professores e estudantes. Esse recurso pode ser importante na tentativa de criar espaços de aprendizagem mais ricos, em momentos presenciais ou à distância. Também pode estimular a pesquisa, incentivar o compartilhamento de experiências, desenvolver competências individuais e possibilitar o trabalho em grupo. E que, o You Tube ${ }^{\circledR}$, mais do que um simples repositório de vídeos, oferece muitas possibilidades para a EAD.
\end{abstract}

PALAVRAS-CHAVE: novas tecnologias na educação, educação à distância, autoria multimídia, vídeo, You Tube.

\begin{abstract}
This study shows that videos are more than a world sensation and can be used by teachers and students. This resource can be important in creating richer learning spaces either to attendance or to distance education. It can also stimulate research, improve experience's exchange, develop personal competences, and enable group work. And, the You Tube ${ }^{\circledR}$, more than what a simple repository of videos, offers many possibilities for the EAD.
\end{abstract}

KEYWORDS: new educational technologies, distance education, multimedia authorware, video, you tube.

\section{Introdução}

O acesso à informação é cada dia mais facilitado pelos meios de comunicação. Seja por jornais, revistas, livros, rádio, televisão ou internet. Sendo que a internet está fundindo esses vários meios em um meio de múltiplos recursos. Múltiplos recursos esses que estão sendo traduzidos por uma palavra muito utilizada hoje - multimídia.

Segundo Kampff e Dias (2003), multimídia significa muitos meios. E na educação, passa a ser uma "estratégia poderosa na utilização de múltiplos recursos que contemplam diferentes percepções do ser humano".

O Dicionário Houaiss (2001) também define a palavra multimídia como "técnica para apresentação de informações que recorre simultaneamente a diversos meios de comunicação, mesclando texto, som, imagens fixas e animadas".

Falkembach (2005), fala sobre o que o professor precisa fazer.

"Para que um software educativo cumpra sua finalidade é preciso que o professor saiba selecionar e planejar os materiais utilizados em sala de aula e melhor ainda se ele for capaz de desenvolver seu próprio material."

Seguindo essa premissa, este trabalho tem como diretriz ajudar professores a produzirem seus próprios materiais, tanto para suas aulas presenciais como para suas aulas em cursos à distância.

Dependendo de como foi planejado e produzido, o vídeo pode ser, por si só, um objeto de aprendizagem. Assim podemos perceber suas potencialidades de uso como uma ferramenta útil para o professor. 


\section{Objetivo}

Demonstrar possibilidades de uso do You Tube ${ }^{\circledR}$ como instrumento pedagógico.

\section{O vídeo na educação}

O vídeo, hoje, transcende a televisão. As imagens não são geradas com a única finalidade de serem usadas na televisão.

A democratização do vídeo é uma realidade. As formas de captação baratearam muito, permitindo que qualquer pessoa com um celular ou uma câmera fotográfica digital, consiga fazer vídeo. E os vídeos resultantes podem ser exibidos na internet, em um arquivo do MS PowerPoint ${ }^{\circledR}$, em um computador, em uma TV, etc.

Mas ainda se passa por uma associação do vídeo com o entretenimento, com o lazer. Segundo Moran(1995), esse é um fator importante, pois ao se usar o vídeo em sala de aula, na cabeça dos alunos, significa lazer e não aula. E isso, quando usado corretamente, atrai o aluno para os assuntos do planejamento pedagógico.

A objetividade do vídeo é impressionante. Carvalho e Gonçalves (2000) explicam que "as imagens do vídeo causam impacto e falam por si mesmas".

O vídeo também tem uma dimensão moderna e lúdica (Moran, 1995). Uma dimensão moderna, pois é um meio de comunicação contemporâneo, novo e que integra várias linguagens. Lúdica, pois permite brincar com a realidade, e mostrá-la aonde quer que seja necessário ou desejável.

Hoje existe uma grande variedade de ofertas de vídeos preparados especialmente para auxiliar e ampliar a tarefa do professor em sala de aula. Essa ajuda é tão representativa que não pode se entender a despensa desses recursos por alguns professores (Figueiredo et al, 1999).

O vídeo é uma ferramenta poderosa ao alcance do professor, pois alcança todos os sentidos (Moran, 1995). Consegue mexer com o corpo todo. Faz com que se experimente sensorialmente o que o outro sentiu. Martirani (1998) relata que "a linguagem videográfica ao articular som e imagem, articula uma rede de signos que orientam o processo comunicativo, ora para a percepção, ora para a cognição".

Outra grande vantagem do vídeo é que, como um audiovisual, requer muito pouco envolvimento e esforço por parte do receptor (Moran, 1995). Ou seja, o receptor recebe as mensagens de uma forma passiva. Direcionam-se mais à afetividade do que à razão. E aí o professor necessita ser ético quanto às mensagens que deseja transmitir.

Moran (1995) afirma que os recursos audiovisuais solicitam constantemente a imaginação, a imaginação está intimamente interligada à afetividade. Por isso, os jovens e a grande maioria dos adultos respondem sensivelmente à linguagem do vídeo.

Há uma dificuldade muito grande de se explorar o potencial das imagens. Ao longo dos séculos, a palavra escrita e falada sempre ocupou destaque na sala de aula (Fundação Roberto Marinho, 1994).

$\mathrm{Na}$ programação de ambientes virtuais para a educação, deve-se utilizar com sabedoria o binômio método/mídia (Alava et al., 2002). O método é tão importante quanto à mídia escolhida. E segundo Carneiro (2001), quando se utilizam várias mídias, conseguem-se abordagens diferentes, representações diferentes e focos diferentes. E com isso a aprendizagem é potencializada. Ainda mais, o papel do professor ou do tutor é insubstituível nessas situações. São eles que ajudam a transpor barreiras e a suavizar ou mesmo resolver conflitos sócio-cognitivos. E segundo Ferreira Filho et al. (2003), essas abordagens vão ao encontro dos estudos desenvolvidos por Piaget(1976, 1978 e 1980) e Vygotsky (2002). 
Moran (1995), inclusive, relata a influência da música e dos efeitos sonoros utilizados no vídeo, pois evocam lembranças de situações passadas, provocando associações. Com isso, se nota um paralelo com a teoria sócio-histórica de Vygotsky.

Como podemos ver, o vídeo é uma poderosa ferramenta ao alcance do professor. Mas a rapidez com que a tecnologia evolui não corresponde ao grau de capacitação dos professores.

E disso, resulta uma utilização inadequada ou até mesmo a falta de utilização desses recursos tecnológicos (Valle, 2003).

Valle (2003), também relata que muitos professores estavam familiarizados com as tecnologias de vídeo e TV em suas casas, mas não conseguiam fazer uso dessas tecnologias como um instrumento pedagógico eficaz. E outros até, por não saberem operar os equipamentos.

Alguns professores acham que vão encontrar a solução de todos os seus problemas no uso do vídeo e da TV em sala de aula. Não percebem que o uso do vídeo não altera a relação pedagógica. $\mathrm{O}$ uso de novas tecnologias em projetos EAD e mesmo presenciais não altera os modelos de ensino-aprendizagem, pois carrega velhas concepções pedagógicas (Andrade,2007). Apesar de todas as oportunidades oferecidas pela tecnologia, o uso do vídeo não adianta nada sem uma boa estrutura pedagógica (Moran, 1995). As tecnologias necessitam de outro elemento que as completem. E Valle (2003) acredita que esse elemento é o professor.

Ele é o elemento de mudança. Ele necessita se preparar para assumir o papel de rotagonista (Carneiro, 2001).

Lima (2002) fala sobre algumas necessidades do professor.

"O vídeo está cada vez mais presente no cotidiano das escolas em todos os níveis de ensino. Se na abrangência deste trabalho não pensamos em propor uma normatização ao seu uso, pelo menos concordamos em que o professor que o utiliza, precisa entender um pouco das linguagens do cinema, da televisão, do vídeo, do modo a usálo com criticidade. Muitas vezes essas questões não estão explícitas e muito ainda precisamos saber sobre o universo de influência deste recurso e desta linguagem, sobretudo imagética."

Mas existe um segredo que faz o aluno participar nesse processo de forma muito ativa. É só torná-lo autor, ou co-autor no processo de criação (Santoro, 1997). Algo que ele participou, u que ele criou, toma uma dimensão muito diferente. E os professores deveriam de lançar mão dessa estratégia mais frequentemente. Ferrés (1996) fala sobre a ação liberadora, provocada pela tecnologia do vídeo quando colocada nas mãos dos alunos. Permite a eles a experiência da pesquisa, do avaliar-se, do conhecer e conhecer-se. Permite a experiência em equipe na elaboração de uma criação coletiva.

Mesmo assim, o professor sempre corre o risco da não aceitação (Carneiro, 2001). Mas o professor não pode se deixar levar apenas pelo medo de errar. "Erre-se mais do que se acerte, seja-se frequentemente ingênuo: desde que se aprenda com o erro e esteja-se disposto a corrigir a ingenuidade." (Braga, 1997).

O professor deve se apropriar das mídias para poder alcançar os seus alunos. A interação midiática enriquece os ambientes de aprendizagem. Torna-os mais atrativos não só para os mais jovens, mas também para os adultos. O aprender torna-se aprazível.

Fischer (2002) fecha o assunto ao escrever:

"Em suma: torna-se impossível fechar os olhos e negar-se a ver que os espaços da mídia constituem-se também como lugares de formação - ao lado da escola, da família, das instituições religiosas."

Não se pode deixar de lado uma ferramenta como essa. O professor deve conhecer o potencial de uso das mídias na sua sala de aula. O professor deve saber manipular as mídias ao seu favor, e a favor do aprendizado de seus alunos. 


\section{O You Tube®}

Foi criado em Fevereiro de 2005 por dois ex-funcionários do eBay®, Steve Chen e ChadHurley (Fortes, 2006). O eBay® é um site norte americano de vendas e leilões que desde2001 é acionista do site brasileiro Mercadolivre.

$\mathrm{O}$ objetivo dessa dupla era possibilitar às pessoas compartilharem seus vídeos de viagens. $\mathrm{E}$ foi com surpresa que viram o seu site se tornar um portal para outra dimensão. O You Tube ${ }^{\circledR}$ chegou à marca de 100 milhões de vídeos assistidos por dia em Julho de 2006 (Fortes, 2006).

A cada dia que passa, são colocados, algo em torno de 65 mil novos arquivos de vídeo digital, à disposição de quem quer assisti-los.

A revista norte-americana Times classificou o You Tube® como a "Invenção do ano" (G1, 2006). Isso surgiu a partir de uma lista elaborada com as melhores invenções do ano em diversas categorias, como brinquedos, roupas, medicina, internet e residências. Mesmo tendo áreas muito diferentes, o You Tube ${ }^{\circledR}$ liderou a lista.

As regras são simples. O arquivo de vídeo tem de ter um tamanho de até $100 \mathrm{MB}$ ou duração de 10 minutos. Além disso, não pode ter copyright, ou pode ser uma produção do próprio autor.

\section{Opções de uso na EAD}

As possibilidades de utilização são várias, como por exemplo: em coursewares, em tutoriais, como material de apoio, como portfólio do aluno ou até mesmo como uma TV educacional.

Isso, apenas alguns exemplos.

O You Tube ${ }^{\circledR}$ pode ser muito útil, principalmente quando se utilizam vídeos. Se os vídeos são armazenados no formato ".flv", ou seja, no formato utilizado pelo Flash ${ }^{\circledR}$, se pode fazer qualquer aplicativo em Flash ${ }^{\circledR}$ que os acesse diretamente. No aplicativo, o link para o vídeo irá indicar a URL fornecida pelo You Tube®. Portanto, quando o usuário dá um clique no botão "play" ou no botão que tem programado a ação de executar o vídeo, o link busca o vídeo no You Tube ${ }^{\circledR}$ e o apresenta na posição pré-programada dentro do aplicativo para que seja apresentado. Desta forma é possível disponibilizar um courseware que se utilize de vídeos, totalmente via internet, de forma gratuita.

Além disso, o aluno tem a possibilidade de postar comentários, pelo You Tube $®$, sobre os vídeos. O desenvolvedor pode programar um link para o usuário acessar externamente ao aplicativo, em outra página, o You Tube®. Assim ele poderá postar seus comentários, ou um pedido de ajuda sobre alguma dúvida, pode ser uma crítica ou pode ser uma resposta a um colega.

Essa técnica tem apenas dois problemas detectados até o momento. Um deles tem a ver com o horário de conecção do usuário. Dependendo do horário, ocorre muita perda de velocidade de comunicação com o You Tube ${ }^{\circledR}$. Isso ocorre por muitos usuários estarem conectados ao mesmo tempo, e, portanto, a banda do You Tube ${ }^{\circledR}$ é dividida pelo número de usuários que o estão acessando. Com isso a transmissão do vídeo fica bastante prejudicada. Pára constantemente. Mas se o usuário tiver paciência, mesmo parando toda a hora, o download é realizado aos poucos, e depois do download o usuário pode repetir a visualização quantas vezes quiser, pois o vídeo já estará disponível off line. Além disso, sempre que o vídeo é apresentado, aparece o logo do You Tube ${ }^{\circledR}$ no canto inferior direito, por sobre a imagem, do começo ao fim. Portanto quem está acessando sabe que o vídeo está no You Tube®. Não tem como esconder. O último problema tem a ver com a privacidade. Quando se faz o upload de um arquivo de vídeo - "Vídeo Upload (Step 2 of 2)", é solicitado o preenchimento de um formulário, e no item "Broadcast", ao se marcar a opção "Public", 
torna esse vídeo visível a todos. Já se for marcada a opção "Private", o vídeo não aparecerá nas buscas realizadas pelos usuários. Para que esse vídeo seja visualizado, a pessoa deverá receber o link por email ou qualquer outro meio de comunicação. Mas, se a pessoa que recebeu o link repassá-lo a mais alguém, essa pessoa também o poderá assistir. Portanto, não se tem uma garantia exata de que só determinadas pessoas possam assistir.

Em tutoriais, se pode dizer que é uma situação mais simples, pois não tem e não precisa de toda aquela estrutura. Às vezes faz-se até sem nenhuma interface, utilizando-se somente o vídeo. Mas, de qualquer forma a utilização é muito idêntica ao caso anterior.

Como material de apoio, é só disponibilizar os vídeos. Ao fazer o upload, tem um formulário onde se pode colocar instruções, dicas ou comentários que aparecerão depois que o vídeo já estiver disponível. É interessante a possibilidade dos alunos postarem comentários sobre o que acharam, e quais as suas opiniões a respeito do assunto tratado.

\section{Como disponibilizar um vídeo pelo You Tube®}

Algumas coisas são necessárias antes que se possa fazer o upload do arquivo. Por exemplo, necessário a gravação das imagens, ou a obtenção via internet. Obviamente é muito importante ter-se cuidado com os direitos autorais. Depois dessa fase, vem o que se chama de "captura", em que se passa o vídeo de uma câmera de vídeo digital para dentro do computador (se a câmera for ainda analógica, diz-se "digitalizar" o vídeo). Hoje pode-se utilizar um celular ou máquina fotográfica digital para se gravar os vídeo. Após se ter o vídeo dentro do computador em formato digital (arquivo .avi, ou .mov, ou .mpg), é necessário editar, ou pelo menos cortar e juntar os pedaços necessários para que o vídeo tenha sentido.

Com o arquivo pronto, é necessário que se faça o cadastro no You Tube®. É muito simples não requer muitas informações.

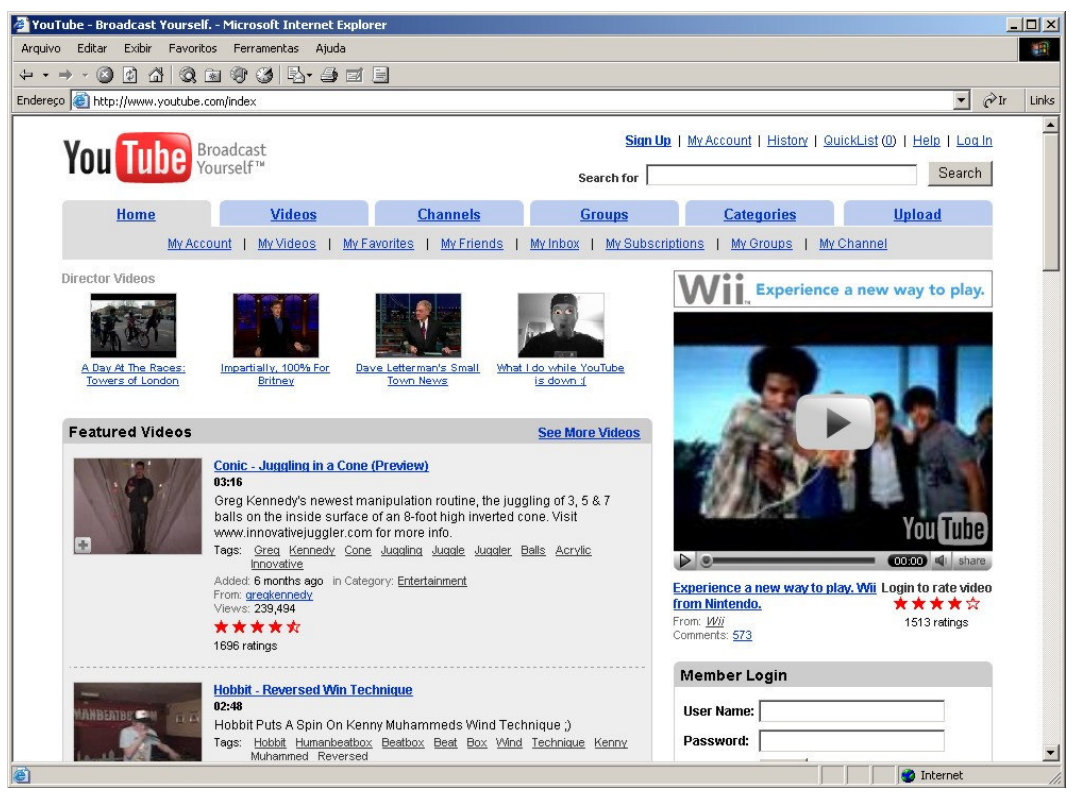

Figura 1 - Interface inicial do You Tube®.

Com o cadastro feito, deve-se proceder ao "login", utilizando-se usuário e senha registrados no cadastro. Pode-se acessar através do menu "Sign Up", ou pela área "Member Login". Após digitar o "User Name" e a "Password", clica-se no botão "Log In". 


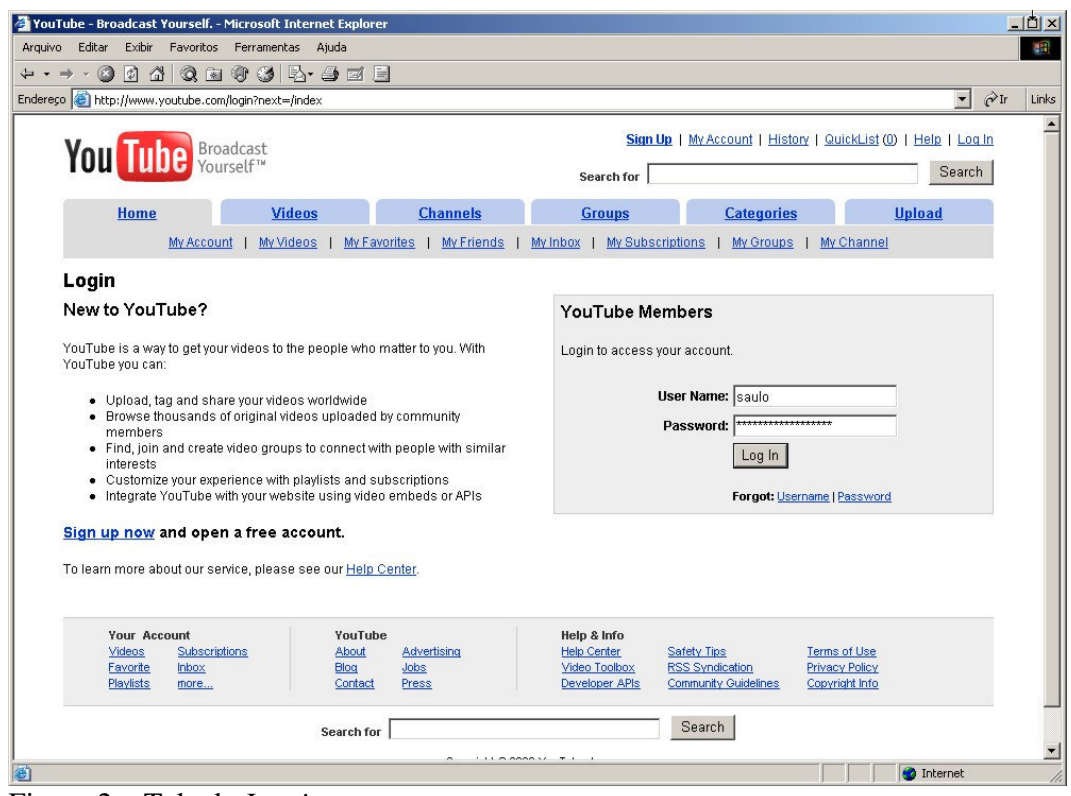

Figura 2 - Tela de Log in

Depois do "Log In" efetuado, deve-se clicar em "My Account", e logo após no botão "Upload New Vídeo".

Deve-se digitar um título breve e objetivo, mas que possa fazer o usuário intuitivamente imaginar o conteúdo. Tem também espaço para uma descrição, onde se podem dar maiores detalhes sobre o vídeo. No campo abaixo, "Tags", é onde se devem colocar as palavraschave, pelas quais, o usuário pode efetuar uma busca. Essas palavras devem estar separadas só por espaços, nada mais.

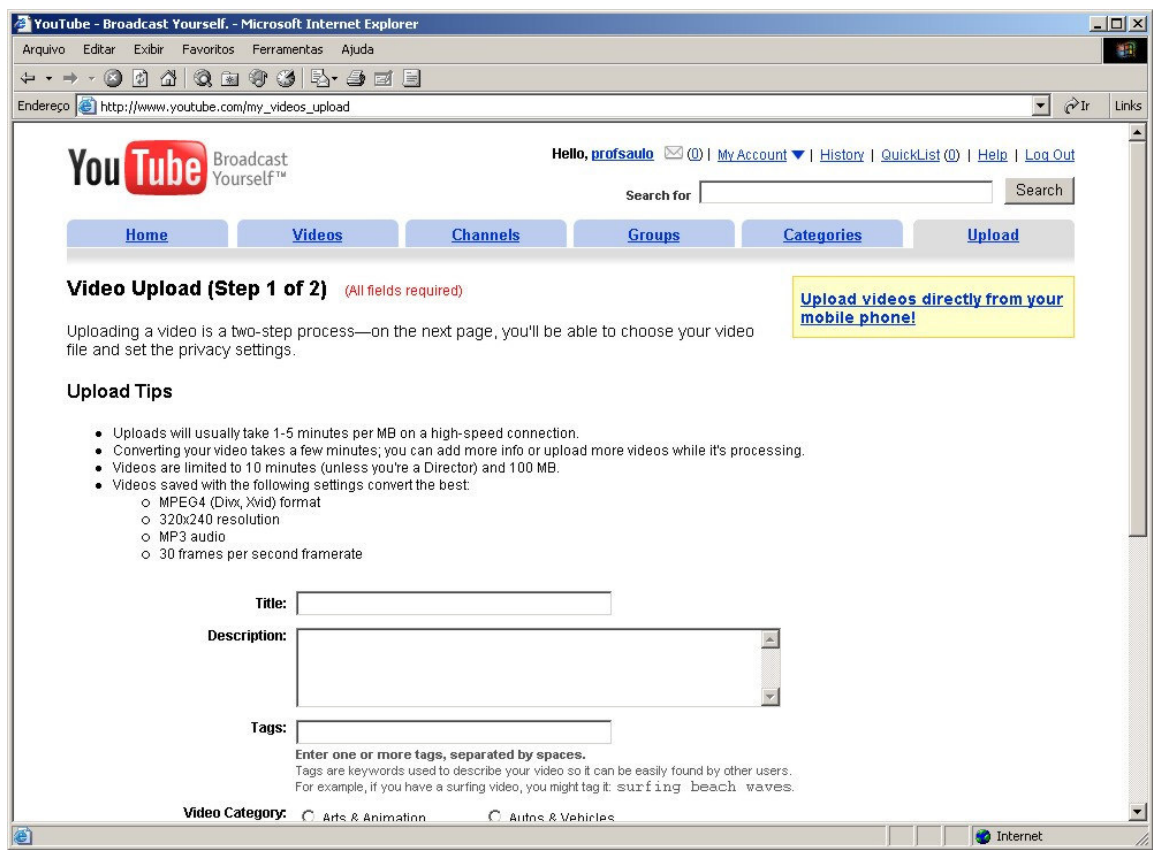

Figura 3 - Título, descrição e Tags de busca. 
Em "Vídeo Category", deve-se escolher a categoria em que o vídeo se encaixa. O You Tube ${ }^{\circledR}$ sugere doze categorias: Artes \& Animação, Comédia, Música, Pessoas, Ciência \&Tecnologia, Viagens \& Lugares, Automóveis \& Veículos, Entretenimento, Notícias \& Blogs, Animais de Estimação, Esportes e Vídeo Games.

Adota-se uma linguagem. E infelizmente o You Tube® não disponibilizou a opção Português. Ele possibilita a escolha entre seis línguas: Inglês, Espanhol, Japonês, Alemão, Chinês e Francês.

Após essa escolha, clica-se em "Continue".

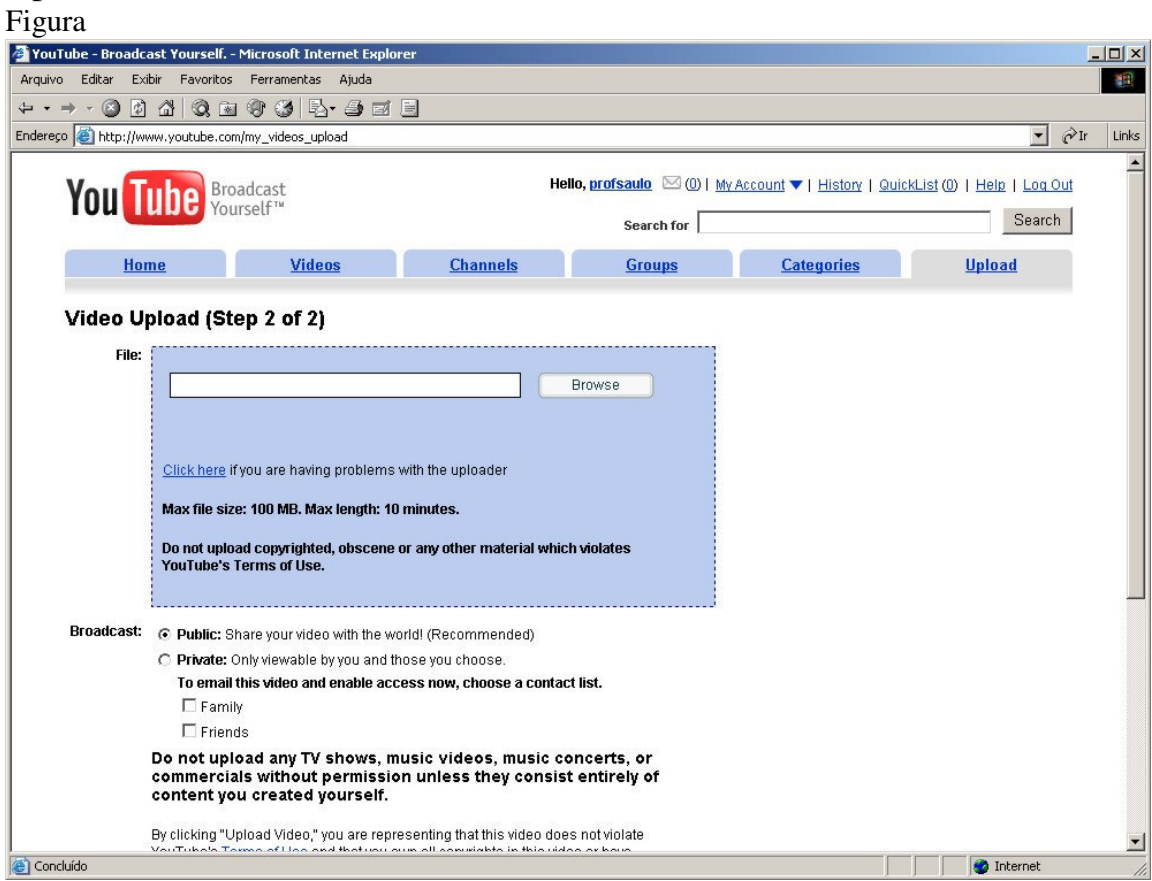

Figura 4 - File e Broadcast

Nesta etapa, clica-se no botão "Browser", dentro do item "File", e seleciona-se o arquivo de vídeo para o upload. Já no item "Broadcast", deve ser escolhida a opção "Public", quando a intenção é disponibilizar o vídeo para qualquer usuário. A opção "Private" só possibilita a visualização de quem possui o link. Então é só clicar no botão "Upload Video".

Neste momento, a paciência deve ser exercida. Dependendo do tamanho do arquivo demora um pouco para o arquivo ir.

Nesta tela, deve-se apenas conferir a primeira parte dos dados que já anteriormente tinham sido solicitadas.

Rolando-se a tela mais para baixo, o formulário pede outros dados, como por exemplo, a ata em que ocorreu o que se está mostrando. Local em que ocorreu, o país e o CEP. No CEP, coloque dois zeros antes, pois do contrário ele reclama que não tem o tamanho correto.

A informação que está em "Public URL" é o link, ou URL que dá acesso ao vídeo que se acabou de postar.

Logo após o item "Broadcast", tem a opção de permitir comentários (Allow Comments). Depois, permitir respostas ao vídeo (Allow Vídeo Responses) e permitir índices de audiência (Allow Ratings).

Finalizando esse formulário, têm-se mais dois itens. Um para permitir o acesso a esse vídeo através de sites externos (Allow External Sites to Embed This Video), e outro muito importante que traz o código HTML já preparado para se conseguir colocar um link a partir de qualquer site. É só selecionar, copiar e colar dentro do arquivo HTML necessário. 


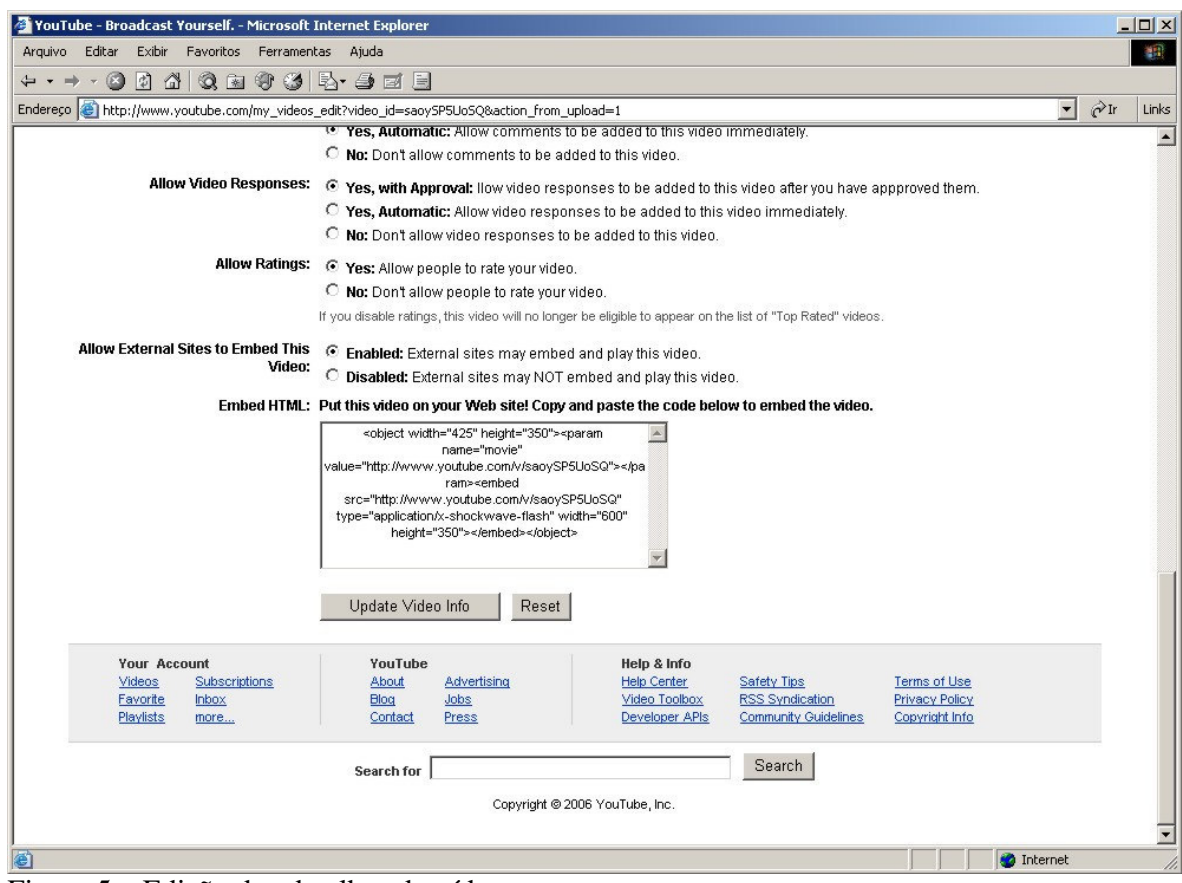

Figura 5 - Edição dos detalhes do vídeo

Clique no botão "Update Vídeo Info" para terminar a publicação do vídeo.

\section{Conclusão}

O vídeo pode ser um instrumento poderoso na mão do professor, havendo a necessidade das escolas e colegas professores se empenharem na diminuição radical do analfabetismo digital entre os professores. Os professores precisam aprender a manusear as ferramentas digitais a seu favor e experimentar o uso das TICs no seu dia-a-dia.

O vídeo não é a solução de todos os problemas que o professor enfrenta em sala de aula. Pelo contrário, a inserção de novas tecnologias na escola pode acabar gerando mais trabalho.

Porém o professor não pode se deixar abalar por isso. É necessário o foco nos resultados. Tentativa e erro, deve ser o alvo. Tentando-se formas diferentes de aplicação, e aprendendose com os próprios erros, pode-se chegar mais próximo da perfeição. E a perfeição para o professor deve ser o aprendizado significativo do seu aluno.

Num estudo futuro será desenvolvido um courseware em que os vídeos ficarão rmazenados no You Tube. Será verificado o desempenho geral, e a aceitação dos alunos.

\section{Referências}

ALAVA, S. et al. Ciberespaço e formações abertas: rumo a novas práticas educacionais?. Porto Alegre: Artmed, 2002.

ANDRADE, ANDRESSA. Uso(s) das novas tecnologias em um programa de formação de professores: possibilidades, controle e apropriações. 2007. 192 f. Dissertação

(Mestrado em Educação) - Faculdade de Educação, Universidade de São Paulo, São Paulo.

BRAGA, J. L.. Meios de comunicação e linguagens: A questão educacional e a interatividade. Revista Linhas Críticas, Brasília, v.5, n.9, jul. a dez. 1999. 
CARNEIRO, VÂNIA LÚCIA QUINTÃO. Linguagem audiovisual e objetivos pedagógicos: uma reflexão sobre os vídeos do Curso TV na Escola e os Desafios de Hoje. In: CONGRESSO INTERNACIONAL DE EDUCAÇÃO A DISTÂNCIA - SEED/MEC -

ABED, 2001. Brasília. Anais Eletrônicos... Brasília: ABED, 2001. Disponível em:

www.mec.gov.br/tvescola. Acesso em: 2 nov. 2006.

CARVALHO, ANNA MARIA PESSOA DE; GONÇALVES, MARIA ELISA RESENDE.

Formação continuada de professores: o vídeo como tecnologia facilitadora da reflexão.

Cadernos de Pesquisa, dez. 2000. Disponível em: < http://www.scielo.br/scielo.php?script=sci_arttext\&pid=S0100-

$15742000000300004 \& \operatorname{lng}=$ pt\&nrm=iso\&tlng=pt>. Acesso em: 9 jun. 2007.

Dicionário Eletrônico Houaiss de Língua Portuguesa. Rio de Janeiro: Editora Objetiva Ltda., [2001], 1 CD-ROM, Ms Windows XP Professional.

FALKEMBACH, GILSE ANTONINHA MORGENTAL. Concepção e Desenvolvimento de Material Educativo Digital. Renote - Revista Novas Tecnologias na Educação, maio. 2005. Disponível em:

$<$ http://www.cinted.ufrgs.br/renote/maio2005/artigos/a23_materialeducativo.pdf $>$. Acesso em: 12 ago. 2006.

FERREIRA FILHO, R. C. M. et al. Produção e implantação do modelo de curso à distância via web. In: XXXI CONGRESSO BRASILEIRO DE ENSINO DE ENGENHARIA, 2003,

Rio de Janeiro. $O$ ensino da graduação e suas interfaces com a pós-graduação, a pesquisa e a extensão. Rio de Janeiro: Instituto Militar de Engenharia, 2003. v. V1. p. 124125 .

FERRÉS, JOAN. Vídeo e Educação. Porto Alegre: Artes Médicas, 1996.

FIGUEIREDO, V. F. et al. Mídia \& Educação. Rio de janeiro: Gryphus, 1999.

FISCHER, ROSA M. B. O Dispositivo Pedagógico da Mídia: Modos de Educar na (e pela)

TV. Educação e Pesquisa, São Paulo (SP), v. 28, n. 1, p. 151-162, 2002.

Fortes, Débora. YouTube. Info, São Paulo, Ano 21, Nº 245 , p. 33-35, ago. 2006.

10 FUNDAÇÃO ROBERTO MARINHO. Vídeo Escola: cinco anos na sala de aula da escola pública brasileira. Rio de janeiro: Fundação Roberto Marinho: Fundação Banco do Brasil, 1994.

KAMPFF, ADRIANA JUSTIN CERVEIRA; DIAS, MÁRCIA GLADIS CANTELLI.

Reflexões sobre a Construção do Conhecimento em Ambientes de Pesquisa e de Autoria Multimídia:Uma Tarefa Compartilhada por Alunos e Professores. Renote - Revista Novas 
Tecnologias na Educação, set. 2003. Disponível em: http://www.cinted.ufrgs.br/renote/set2003/artigos/adriana_justin.pdf. Acesso em: 2 nov. 2006.

MARTIRANI, LAURA ALVES. In: CONGRESSO INTERNACIONAL SOBRE COMUNICAÇÃO E EDUCAÇÃO, 1998, São Paulo. O vídeo no ensino universitário: uma experiência com a Pedagogia da Comunicação. São Paulo: ECA - Escola de Comunicação e Artes da USP, 1998. Disponível em: http://www.eca.usp.br/nucleos/nce/pdf/094.pdf>. Acesso em: 9 jun. 2007.

MORAN, José Manuel. O vídeo na sala de aula. Comunicação \& Educação, São Paulo, jan./abr. de 1995. Disponível em: <http://www.eca.usp.br/prof/moran/ vidsal.htm>. Acesso em: 10 jul. 2006.

PIAGET, J.. Ensaio de lógica operatória. Porto Alegre: Globo, 1976.

PIAGET, J.. Epistemologia Genética. São Paulo: Abril, 1978.

PIAGET, J.. O nascimento da inteligência na criança. São Paulo: Zahar, 1980.

SANTORO, FLÁVIA et al.. Autoria cooperativa de crianças em sistemas hipermídias: relato de uma experiência. In: ED-MEDIA .1997, Calgary. Anais... Calgary, 1997.

Tecnologia. G1 - O portal de notícias da Globo, São Paulo, 7 de nov. 2006. Disponível em:<http://g1.globo.com/Noticias/Tecnologia/0,,AA1340903-6174-363,00.html>. Acesso em: 12 nov. 2006.

VALLE, LUCIANA R. L. D.; CRUZ, DULCE M.. Reinventando a TV e o vídeo na escola: Uma experiência com a TV Escola e os professores da Rede Estadual de Ensino do Paraná.

Athena - Revista Científica de Educação, Vol. 1, Número 1, jun./set. 2003. Disponível em: <http://www.uniexp.edu.br/revista_athena/Revista\%20Athena_set2003.pdf > Acesso em 2 de nov. 2006.

VYGOTSKY, L. S.. A formação social da mente. São Paulo: Martins Fontes, 2002 